\title{
Study of additional mechanism of short time delay detection in input signal by the homological neural network Viacheslav A Vasilkov* and Ruben A Tikidji-Hamburyan
}

\author{
Address: A.B. Kogan Research Institute for Neurocybernetics, Southern Federal University, Rostov-on-Don, Russia \\ Email: Viacheslav A Vasilkov* - vva@nisms.krinc.ru \\ * Corresponding author
}

from Seventeenth Annual Computational Neuroscience Meeting: CNS*2008

Portland, OR, USA. 19-24 July 2008

Published: I I July 2008

BMC Neuroscience 2008, 9(SuppI I):PI2 doi: I0.I I86/I47I-2202-9-SI-PI2

This abstract is available from: http://www.biomedcentral.com//47I-2202/9/SI/PI2

(c) 2008 Vasilkov and Tikidji-Hamburyan; licensee BioMed Central Ltd.

Sound source localization by the binaural hearing system occurs due to amplitude and time differences between signal arrivals into left and right ears [1]. To localize a sound source with a high resolution, the auditory system has to detect short time delays (STD) which are significantly less than any time constant of individual neural network elements. Thus, if short sound clicks are localized by human auditory systems with $5^{\circ}$ resolution the value of interaural STD detected by the nervous system should be approximately 10 microseconds, while a time constant of a system individual element is not less than 700 microseconds $[1,2]$. The most known and investigated mechanism allowing detecting STD with such high accuracy is the mechanism based on the coincidence detectors [1-3]. But since such mechanism requires a continual periodical signal, this issue is still open. Here we present another STD detection mechanism based on the comparison of impulse activity of two symmetric populations of neurons accounted for in the auditory cortex, so called E-I neurons [4]. These cells are activated by contralateral ear stimulation and otherwise are inhibited when ipsilateral stimulation occurs. E-I neurons have slow reaction to a change of sound source location, and that is why such neurons are regarded as rough detectors of the sound source location.

However, the preliminary results which were obtained with the simplified model of the E-I cell population showed that the comparatively large population of such cells can detect STD with a high accuracy [2]. Similar to [2] the present research is based on the artificial neural network model which simulates the behavior of two E-I neuron populations under dichotic stimulation. To obtain more biologically adequate results we use a more complicated representation of synaptic transmission (a - synapse [1]) in the analytical study and a non-linear single element (neural model of E. Izhikevich [5]) activated by a synaptic reverse model [6] in the numerical simulations. The proposed model also shows a robust STD detection in the case when bi-polar white noise with different amplitude is present in the single networks element activity. Reducing noise influence by increasing population size is also illustrated. We show that the results obtained in simulations are well correlated with psychophysical test observations [7].

The obtained results allow us to suggest that the described mechanism contributes to the well-known system of sound source localization based on coincidence detectors.

\section{References}

I. Gerstner W, Kistler WM: Spiking Neuron Models. Single Neurons, Populations, Plasticity. Cambridge University Press; 2002.

2. Tikidji-Hamburyan R, Polevaya S: Sound-source localization by neural network based on modified integrate-and fire neuron model with autopolarization. Thirteenth Annual Computational Neuroscience Meeting (CNS), Abstract book 2004:96.

3. Joris $\mathrm{PX}, \mathrm{Smith} \mathrm{PH}, \mathrm{Yin} \mathrm{T}$ : Coincidence detection in the auditory system: $\mathbf{5 0}$ years after Jeffreys. Neuron 1998, 21: I 235-1238.

4. Liu W, Suga N: Binaural and commissural organization of the primary auditory cortex of the mustached bat. J Comp Physiol 1997, I 81 : 599-605.

5. Izhikevich EM: Simple model of spiking neurons. IEEE Transactions on Neural Networks 2003, 14:1569-1572.

6. Compte A, Sanchez-Vives MV, McCormick DA, Wang X-J: Cellular and network mechanisms of slow oscillatory activity $(<\mathrm{l} \mathrm{hz})$ and wave propagations in a cortical network model. $J$ Neurophysiol 2003, 89:2707-2725. 
7. Polevaya SA, Antonets VA, Eremin EV: A sensor scale of spatial human hearing in a virtual acoustic space. Sensor systems 2002, 16:291-296. (In Russian).

Publish with Bio Med Central and every scientist can read your work free of charge

"BioMed Central will be the most significant development for disseminating the results of biomedical research in our lifetime. " Sir Paul Nurse, Cancer Research UK

Your research papers will be:

- available free of charge to the entire biomedical community

- peer reviewed and published immediately upon acceptance

- cited in PubMed and archived on PubMed Central

- yours - you keep the copyright

Submit your manuscript here:

http://www.biomedcentral.com/info/publishing_adv.asp 